\title{
Archaeological Investigations Within the Right-of-way of IH 27 at Yellowhouse Draw Lubbock County, Texas
}

Jerry Henderson

Follow this and additional works at: https://scholarworks.sfasu.edu/ita

Part of the American Material Culture Commons, Archaeological Anthropology Commons, Environmental Studies Commons, Other American Studies Commons, Other Arts and Humanities Commons, Other History of Art, Architecture, and Archaeology Commons, and the United States History Commons

Tell us how this article helped you.

This Article is brought to you for free and open access by the Center for Regional Heritage Research at SFA ScholarWorks. It has been accepted for inclusion in Index of Texas Archaeology: Open Access Gray Literature from the Lone Star State by an authorized editor of SFA ScholarWorks. For more information, please contact cdsscholarworks@sfasu.edu. 


\section{Archaeological Investigations Within the Right-of-way of IH 27 at Yellowhouse Draw Lubbock County, Texas}

\section{Licensing Statement}

This is a work produced for the Texas Department of Transportation (TxDOT) by the report producer. TxDOT and the report producer jointly own all rights, title, and interest in and to all intellectual property developed under TXDOT's contract with the report producer. The report may be cited and brief passages from this publication may be reproduced without permission provided that credit is given to both TXDOT and the report producer. Permission to reprint an entire chapter, section, figures or tables must be obtained in advance from either the Supervisor of the Archeological Studies Branch, Environmental Affairs Division, Texas Department of Transportation, 125 East 11th Street, Austin, Texas, 78701 or from the report producer. 
ARCHAEOLOGICAL INVESTIGATIONS WITHIN THE RIGHT-OF-WAY OF IH 27

AT YELLOWHOUSE DRAW

LUBBOCK COUNTY, TEXAS

By

Jerry Henderson

Texas

State Department of Highways and Public Transportation

Highway Design Division

March 1986 


\section{ABSTRACT}

Machine testing was conducted by the State Department of Highways and Public Transportation in a small area bounded by the right-of-way of $\mathrm{IH}$ 27 on the north side of Yellowhouse Draw in Lubbock County, Texas. The area was tested because of the high probability of buried cultural materials; however, no archaeological materials were encountered. Soil deposits equating to the Archaic and Ceramic Periods at the Lubbock Lake Site (Strata 3, 4, and 5 at Lubbock Lake) were present but they did not contain remains of a material culture. 


\section{INTRODUCTION}

From January 16 to February 4, 1986, archaeological testing was performed by a member of the cultural resources staff of the State Department of Highways and Public Transportation (SDHPT) along the north side of Yellowhouse Draw in the area to be affected by construction of IH 27 i n Lubbock, Texas (Fig. 1). Testing was conducted in accordance with both state and federal procedures, including Procedures for the Protection of Historic and Cultural Properties (36 CFR, Part 800), procedures prescribed and endorsed by the Federal Highway Administration. Testing was performed in order to determine the presence or absence of cultural resources within the roadway right-of-way. Had cultural properties been found during this initial testing, then further work may have been required to determine eligibility for inclusion in the National Register of Historic Places and/or State Archaeological Landmark status.

A series of machine trenches was excavated into the deposits of the Draw in an attempt to locate buried archaeological materials. Although previous pedestrian surveys had determined that there was no surficial archaeological evidence, it was felt that subsurface testing was necessary to confirm the presence/absence of buried archaeological remains. This decision was prompted by the fact that known archaeological sites exist along the length of the Draw at depths up to $35 \mathrm{ft}$. and many of the sites are covered by a recent soil mantle which obscures the nature of the prehistoric deposits (C. Johnson 1974; Stafford 1977, 1978; Holliday 1985; Johnson and Holliday 1986; E. Johnson, personal communication, 1986). Therefore, testing was initiated solely to determine whether archaeological materials did indeed exist within the project boundary. No archaeological evidence was encountered.

Placement of test trenches was limited in part by the presence of existing roadways and buried utilities. Additionally, testing was limited-- 
both horizontally and vertically--to those areas where actual construction was planned to occur; that is, in the areas of actual land modifications (Fig. 1). It was felt that if the highway construction could, avoid encroaching upon intact buried deposits, then the archaeological testing should avoid those areas as well.

Testing was confined, therefore, to the northern side of the Draw, in a narrow strip of land paralleling the streambed for approximately $1200 \mathrm{ft}$. and extending to a maximum of $250 \mathrm{ft}$. up the northern slope of the Draw (Fig. 1). Construction plans call for rechanneling the present streambed in this area. The new channel will be cut an average of $7 \mathrm{ft}$. deep into the existing terrace, and the adjacent banks will be reterraced to accommodate the new channel. The old channel will be filled and a park road and hike-and-bike trail will be created in the area of the original streambed.

The remaining project area will be unaltered except for drill shafts for bridge foundations which will be 30 to 36 in. in diameter and up to $25 \mathrm{ft}$. deep. The drill shaft localities were not tested because it was felt that machine trenching would cause considerably more damage to the intact deposits than the shaft drilling procedure. 


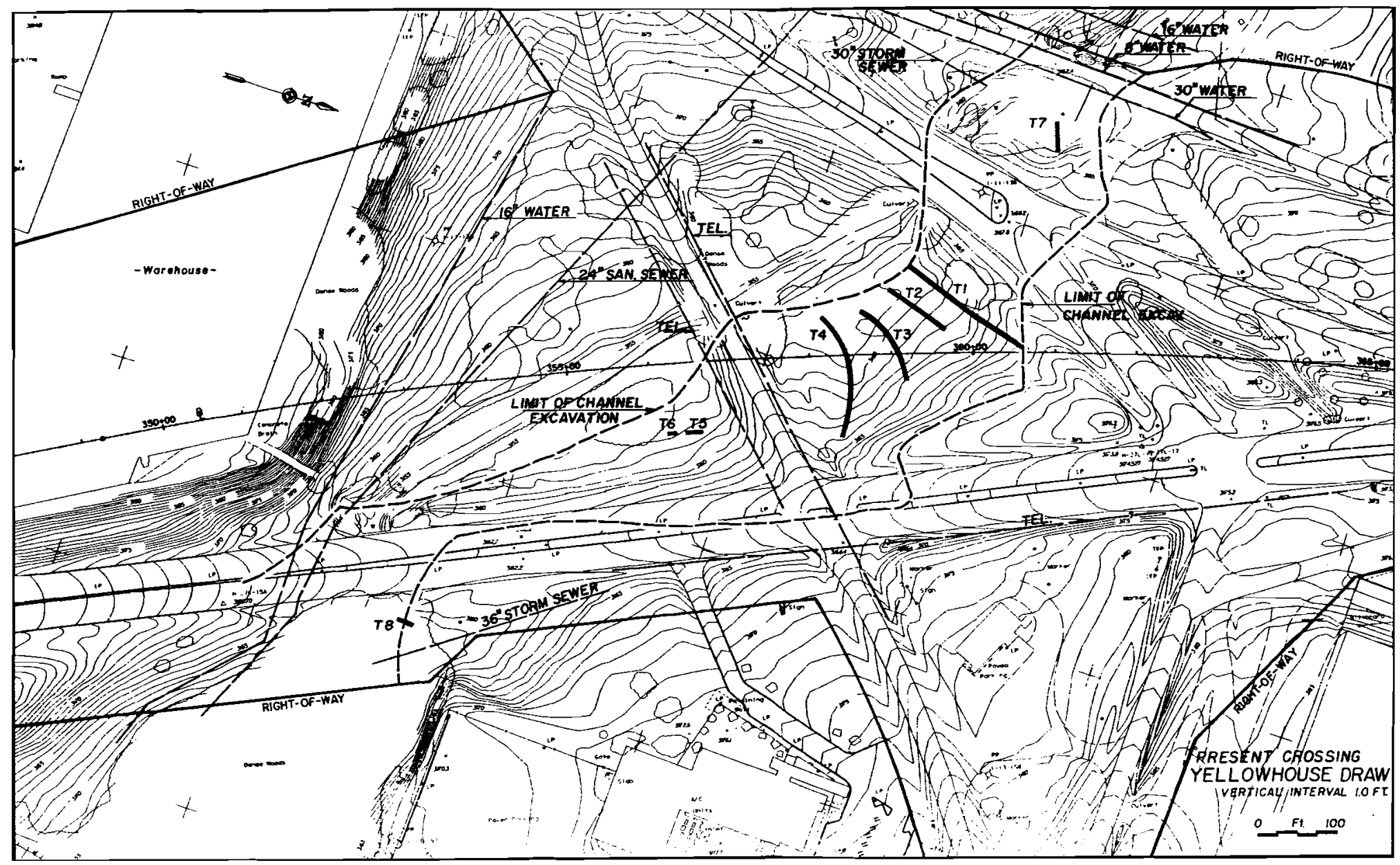

FIGURE 1. Project map showing location of Gradall trenches 


\section{TESTING PROCEDURES}

A series of 8 Gradall trenches was excavated into the area (Fig. 1). The depth of each trench was determined by the depth of the proposed cut in that area. In other words, if the construction plans called for a $6-\mathrm{ft}$. cut in a particular area, then the Gradall testing extended only to $6 \mathrm{ft}$. in that same area. Likewise, where plans called for only a 2-ft. cut, Gradall testing consisted of only a 2-ft.-deep trench. In this way, a sample of the entire impact area was investigated. The maximum depth reached in each trench is presented in Table 1.

The water table was reached in all trenches at approximately $5 \mathrm{ft}$. depth. At this depth, water began to seep into the trenches, necessitating the use of power-driven pumps to keep the trenches free of standing water. The water was pumped out of the trenches and into the Yellowhouse Draw streambed.

TABLE 1. Maximum depth reached in each Gradall trench.

\begin{tabular}{c|c}
\hline Trench No. & $\frac{\text { Maximum Depth }}{}$ \\
\hline 1 & $7 \mathrm{ft}$. \\
2 & $8 \mathrm{ft}$. \\
3 & $8 \mathrm{ft}$. \\
4 & $8 \mathrm{ft}$ \\
5 & $6 \mathrm{ft}$. \\
6 & $7 \mathrm{ft}$. \\
7 & $10 \mathrm{ft}$ \\
8 & $8 \mathrm{ft}$. \\
\hline \hline
\end{tabular}




\section{STRATIGRAPHY}

The stratigraphy exposed during the trenching procedure was markedly uniform in all trenches and was comparable to the stratigraphy at the Lubbock Lake Site (E. Johnson, personal communication, 1986) which is located about 1.5 miles upstream from the present SDHPT investigations.

At the Lubbock Lake Site, a sequence of five major strata has been recognized (Fig. 2). Corresponding archaeological materials and radiocarbon dates have served to further define the sequence. The combined data have led to a "closely integrated record of late Quaternary human occupation, sedimentation, and soil formation" for the area (Holliday 1985). Investigators at the Lubbock Lake Site believe that the defined sequence is applicable in general to the entire Yellowhouse Draw (E. Johnson, personal communication, 1986).

Briefly, Stratum 1 is the oldest deposit containing cultural remains. It has been dated to 11,000 B.P. and contains Clovis materials. Stratum 2 has been dated from 11,000 B.P. to 6300 B.P. The lower Stratum 2 deposits contain Paleo-Indian materials, and the upper Stratum 2 deposits contain Early Archaic materials. Stratum 3 has been dated at 6300 B.P. to 5000 B.P. and contains Early and Middle Archaic materials. Stratum 4 has been dated at 5000 B.P. to 1000 B.P. and coincides with the Late Archaic and Ceramic Periods of cultural occupation. Stratum 5 represents the last 1000 years and contains Late Ceramic, Protohistoric, and Historic materials (Holliday 1985; Johnson and Holliday 1986).

During the SDHPT investigations, only Stratum 5 was present in all the trenches. Stratum 4 and occasionally the uppermost portion of Stratum 3 were sometimes encountered in the bottom of some trenches. Trenching did not extend to great enough depths to expose Strata 1 and 2. A recent fill, sometimes as thick as 1 meter, overlay the established sequence throughout the area. The fill was highly disturbed and contained metal fragments, pieces of plastic, glass fragments, and chunks of cement. 


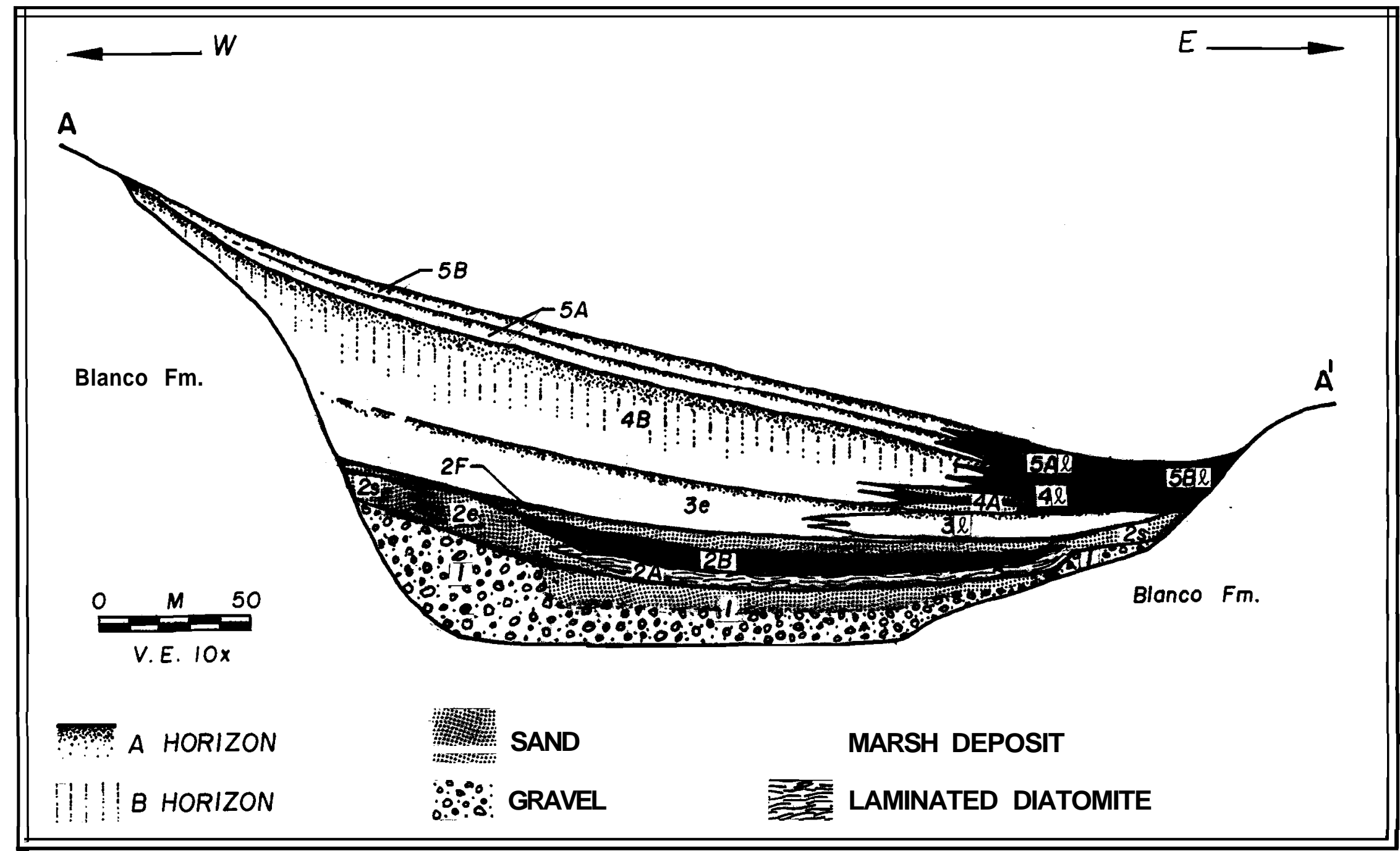

FIGURE 2. Generalized stratigraphy of Yellowhouse Draw as defined at the Lubbock Lake Site (from Holliday 1985). Vertical subdivisions are identified using uppercase letters (A, B, etc.), and lateral subdivisions (facies changes) are identified using lowercase letters for the mode of deposition $(\mathrm{e}=\mathrm{eolian}$, $\mathrm{s}=. \mathrm{slope}-$ wash $I=$ lacustrine). 


\section{RESULTS}

No cultural remains were encountered during the investigations.

However, several bone fragments were recovered from the walls and floors of the trenches as well as from the backdirt. Table 2 presents data derived from the bones. No butchering marks or other evidence was present to indicate that human agents were responsible for the deposition of the bones. It appears that the bones were the result of natural deaths.

Since the area under investigation was considered to be a high probability area for the recovery of archaeological remains and since quantities of bone, especially Bison sp., were associated with cultural occupations at Lubbock Lake and other sites, consultant opinions were sought from a geologist, a paleontologist, and an archaeologist who have worked in the area. Consequently, Drs. C. C. "Tex" Reeves, Earl Green, and Eileen Johnson from Texas Tech University visited the locale and inspected the recovered fauna. They concurred that no evidence of cultural occupation existed and that the bones were probably the result of natural deaths. 
TABLE 2. Faunal data.

\begin{tabular}{|c|c|c|c|}
\hline ID No. & Species & Element & Provenience \\
\hline 1 & Unidentifiable & Unidentifiable & $\begin{array}{l}\text { Stratum3, Trench, } \\
1.50 \text { meters below } \\
\text { ground surface, } 8 \\
\text { meters north of } \\
\text { southend of trench }\end{array}$ \\
\hline 2 & $\begin{array}{l}\text { Bison bison } \\
\text { (juvenile) }\end{array}$ & Femur & $\begin{array}{l}\text { Stratum } 5, \text { Trench } 1 \text {, } \\
\text { we } \notin \text { wall, } 70 \mathrm{~cm} \\
\text { below ground eurface, } \\
8 \text { meters north of } \\
\text { south end of trench }\end{array}$ \\
\hline 3 & Unidentifiable & Unidentifiable & $\begin{array}{l}\text { Stratum } 5, \text { Trench } 1 \text {, } \\
\text { eaet wall, } 75 \mathrm{~cm} \\
\text { below ground surface, } \\
7.4 \text { meters north of } \\
\text { south end of trench }\end{array}$ \\
\hline 4 & Bison bison & Vertebra & $\begin{array}{l}\text { Stratum } 3, \text { Trench } 1 \text {, } \\
\text { eaet wall, } 1.55 \text { meters } \\
\text { below ground surface, } \\
7.85 \text { meters north of } \\
\text { south end of trench }\end{array}$ \\
\hline 5 & Unidentifiable & Unidentifiable & $\begin{array}{l}\text { Stratum } 5, \text { Trench } 2, \\
\text { west wall, } 35 \mathrm{~cm} \\
\text { below ground surface, } \\
4.80 \text { meters north of } \\
\text { south end of trench }\end{array}$ \\
\hline 6 & Bidon ben & $\begin{array}{l}3 \text { teeth and } \\
\text { mandible } \\
\text { fragments }\end{array}$ & $\begin{array}{l}\text { Stratum } 4, \text { Trench } 4, \\
\text { eaet wall, } 1.45 \text { meters } \\
\text { below ground eurface, } \\
16 \text { meters south of } \\
\text { north end of trench }\end{array}$ \\
\hline 7 & Bion bion & $\begin{array}{l}\text { Long bone } \\
\text { fragment }\end{array}$ & $\begin{array}{l}\text { Stratum } 4, \text { Trench } 4, \\
\text { east wall, } 1.45 \text { meters } \\
\text { below ground surface, } \\
14.40 \text { meters south of } \\
\text { north end of trench }\end{array}$ \\
\hline 8 & Unidentifiable & Unidentifiable & $\begin{array}{l}\text { Stratum } 5, \text { Trench } 3, \\
\text { east wall, } 25 \mathrm{~cm} \text { below } \\
\text { ground surface, } 6.55 \\
\text { meters north of south } \\
\text { end of trench }\end{array}$ \\
\hline 9 & 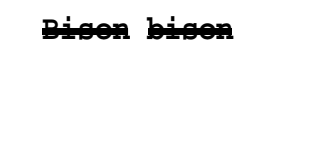 & Metapodial & $\begin{array}{l}\text { Stratum 5, Trench 2, } \\
\text { backdirt fromapprox. } \\
4.80 \text { meters north of } \\
\text { south end of trench }\end{array}$ \\
\hline 10 & $\begin{array}{l}\text { Small mammal } \\
\text { (fox-size) }\end{array}$ & Ulna & $\begin{array}{l}\text { Stratum } 5 \text {, Trench } 8 \text {, } \\
\text { backdirt }\end{array}$ \\
\hline
\end{tabular}




\section{SUMMARY}

No evidence of cultural occupation was found in that area of Yellowhouse Draw bounded by the IH 27 right-of-way. Strata 5, 4, and uppermost 3, as defined at the Lubbock Lake Site and elsewhere in the Draw, were present in the trenches. Their presence indicates that the Archaic and Ceramic time periods were represented even though cultural occupation was lacking. Faunal remains, mostly bison, were recovered from a 11 three strata but appeared to be the result of natural deaths. If future construction other than planned drill shafts for bridge foundations should impact the lower deposits (Strata 1, 2, and 3), then further archaeological testing will be necessary. However, at the present time these lower deposits will be preserved intact and no further work is recommended. 
REFERENCES CITED

Holliday, Vance T.

1985 Archaeological Geology of the Lubbock Lake Site, Southern High Plains of Texas. Geological Society of America Bulletin 96:1483-1492.

Johnson, Charles A., III

1974 Geologic Investigations at the Lubbock Lake Site. West Texas Museum Association Journal 15:79-105.

Johnson, Eileen

1986 Personal communication with Jerry Henderson while visiting the State Department of Highways and Public Transportation IH 27 Yellowhouse Draw investigations, February 4, 1986.

Johnson, Eileen, and Vance T. Holliday

1986 The Archaic Record at Lubbock Lake. In: Timothy Baugh (Ed.), Current Trends in Southern Plains Archaeology. Plains Anthropologist Memoir.

Stafford, T. W.

1977 Late Quaternary Alluvial Stratigraphy of Yellowhouse Draw, Lubbock, Texas. In: Johnson, E., and Stafford, T.W.

(Eds.), Cultural Adaptation to Ecological Change on the Llano Estacado: Preliminary report of the 1977 field season of the Lubbock Lake Project, submitted to the National Science Foundation.

1978 Late Quaternary Alluvial Stratigraphy of Yellowhouse and Blackwater Draws, Llano Estacado, Texas. In: Johnson, E. (Ed.), Cultural Adaptation to Ecological Change on the Llano Estacado. Preliminary Report of the 1977 Field Season of the Lubbock Lake Project, submitted to the National Science Foundation. 